\title{
Sanrachna
}

\section{Bioinformatics Innovation \& Intellectual Property Rights}

Divyansh Sehgal ${ }^{1}$

\begin{abstract}
Bioinformatics is an ever-growing field due to the availability of vast database systems and increasing biological data. This rapid development deals with research and development activities and requires adequate protection in the form of Intellectual Property Rights(IPR) as it adds value to the discoveries and provides incentives to the investors. The study includes the role of IPR in bioinformatics with a major focus on patents and related laws. The paper will also analyze, what type of bioinformatics are patentable, how does patent protect bioinformatics innovations specifically software which analyses DNA sequences. The paper will be presented in four parts namely, part one will consist of the introduction, while the part two will focus on what is bioinformatics and how it is related to IPR, part three will focus on the patent eligibility criteria for bioinformatics and lastly, part four will present a conclusion.
\end{abstract}

Keywords: Bioinformatics, patents, omics, DNA sequence, Intellectual property rights.

\section{A. Introduction}

The rapid developments since the last two decades in the field of biotechnology have resulted in new methods, products for the advancement of many sectors such as the pharmaceutical industry, diagnostics, environment, food tech, agriculture ${ }^{2}$. Recent sequence explosions all around the globe have also resulted in sequencing the whole genome of microbes, animals, plants while along with the explosion of sequence issues of patents about deoxyribonucleic acid(DNA) and ribonucleic acid(RNA) and other related technologies ${ }^{3}$. Nowadays, the vast amount of information about the human genome has increased the potential of bioinformatics innovations worldwide as it is available online free in the databases maintained and developed by various bio-ventures and research organizations. Bioinformatics has many uncertainties when it comes to patent eligibility, some can utilize a composition of matter or is a product of manufacture claims but the most common bioinformatics innovations are in the field of software processes which is difficult to obtain ${ }^{4}$. DNA and gene-related technologies are

\footnotetext{
${ }^{1}$ Legal Research Associate, Sanrachna

${ }^{2}$ Yadav D, Anand G, Kumar A, Gupta S, Yadav S. Patents in the Era of Genomics: An Overview [Internet]. Department of Biotechnology; 2012 [cited 10 July 2020]. Available from: https://www.researchgate.net/publication/225274845_Patents_in_the_Era_of_Genomics_An_Overview ${ }^{3}$ Ibid

${ }^{4}$ Karky R. Bioinformatics innovations and patent eligibility [Internet]. The Journal of World Intellectual Property, John Wiley \& Sons Ltd; 2018 [cited 10 July 2020]. Available from: https://onlinelibrary.wiley.com/doi/epdf/10.1111/jwip.12101
} 


\section{Sanrachna}

influencing and encouraging medical research which provides solutions to various incurable diseases and the development of safe and efficient drugs that are affordable.

Biological data is growing at a fast speed, for example, the number of sequences in GenBank Increased from 606 in 1982 to 201,663,568 in 2017 and it doubles its size every 15 months 5 . Bioinformatics is used in numerous areas such as gene therapy, drug development, molecular medicine, preventive medicine, crop improvement, insect resistance studies, etc. Determining the function of a gene can help in making pharmaceutical drugs, but to ascertain the function of a gene DNA must be analyzed in sophisticated laboratory techniques and complex computer algorithms ${ }^{6}$. Genome research aims at the analysis of proteins that are encoded by particular DNA sequences, single nucleotide polymorphism (SNP) analyses, and the mutation of genes that are associated with the disease ${ }^{7}$. For example treatment of a fungal infection, the researcher might examine its DNA or mRNA by sequencing which results in a list of genes in the human genome and remove the unwanted genes ${ }^{8}$.

\section{B. Bioinformatics and its relation with IPR}

Bioinformatics involves programs that produce everything from a spot-picking microarray machine to genome-wide blast search, to complex protein modeling software packages which makes bioinformatics to be unique from the other disciplines of science such as computer science, biology, etc $^{9}$. Bioinformatics deals with the collection, storage, compilation, access, management, and processing of information to understand the science behind DNA to find new treatment techniques or better drugs with reduced time and cost-efficiency.

Definition by Merriam-Webster: the collection, storage, classification, and analysis of biochemical and biological information using computers, applying to genomics ${ }^{10}$.

\footnotetext{
${ }^{5}$ Shilpa, Gupta U. (2018) Intellectual Property Rights and Bioinformatics: An Introduction. In: Shanker A. (eds) Bioinformatics: Sequences, Structures, Phylogeny. Springer, Singapore

${ }^{6}$ Mochida, K., \& Shinozaki, K. (2011). Advances in omics and bioinformatics tools for systems analyses of plant functions. Plant \& cell physiology, 52(12), 2017-2038. https://doi.org/10.1093/pcp/pcr153

${ }^{7}$ Ibid

${ }^{8}$ Karky R. Bioinformatics innovations and patent eligibility [Internet]. The Journal of World Intellectual Property, John Wiley \& Sons Ltd; 2018 [cited 10 July 2020]. Available from: https://onlinelibrary.wiley.com/doi/epdf/10.1111/jwip.12101

${ }^{9}$ Shenoy R. Bioinformatics Patents - The Challenges [Internet]. Journal of Commercial Biotechnology; 2016 [cited 15 July 2020]. Available from: https://www.researchgate.net/publication/312516488_Bioinformatics_Patents_-_The_Challenges ${ }^{10}$ Definition of BIOINFORMATICS [Internet]. Merriam-webster.com. 2020 [cited 15 July 2020]. Available from: https://www.merriam-webster.com/dictionary/bioinformatics
} 


\section{Sanrachna}

Bioinformatics has been contributing greatly towards the fields of pharmaceuticals, agriculture, medicine, and drugs. The area of proteomics and genomics are dependent upon bioinformatics that is DNA sequencing by which vast complex biological data is converted into useful information which helps in the discovery of virulence factors and effective drug targets for ascertaining the human diseases genes ${ }^{11}$. Therefore pharmacogenomics, genomics, proteomics as well as other fields such as transcriptomics, metabolomics, phenomics, epigenetics along computer-aided drug design research are the components of bioinformatics which have transformed this field of bioinformatics to a massive commercial struggle.

The intellectual Property right is a legal right that is given to an inventor of an original creation developed by his intellect, skill, and labor. As investments in R\&D are increasing the stakes of innovators in knowledge creation have become high as IPR gives two principles for the development of the IPR i.e. incentives to the inventor and economic and social welfare of the state $^{12}$. IPR protection in bioinformatics is necessary for encouraging and fostering innovation as a new area, as bioinformatics requires investments and investors would only be interested if there is an assurance to recoup their investment and as it is known that IPR protection ensures profits and is very helpful in bringing a drug or a therapeutic product to the market ${ }^{13}$.

\section{What are Genes?}

Genes are made up of stretches of deoxyribonucleic acid (DNA) which are founding the nucleus of the cell. A nucleotide is a building block of DNA and there are 4 types of nucleotides such as adenine (A), cytosine (C), thymine (T), and guanine (G) and in case of RNA instead of thymine $(\mathrm{T})$, uracil $(\mathrm{U})$ takes place ${ }^{14}$. Genes are specific lengths of DNA that ascertain the order of amino acids used to make proteins that are needed for the smooth functioning of all cells ${ }^{15}$. When the four nucleotides are in a certain order they are known as DNA sequence which contains the genetic information coding for proteins. Genetic information is a valuable input in

\footnotetext{
${ }^{11}$ Shenoy R. Bioinformatics Patents - The Challenges [Internet]. Journal of Commercial Biotechnology; 2016 [cited 15 July 2020]. Available from: https://www.researchgate.net/publication/312516488_Bioinformatics_Patents_-_The_Challenges 12 Shilpa, Gupta U. (2018) Intellectual Property Rights and Bioinformatics: An Introduction. In: Shanker A. (eds) Bioinformatics: Sequences, Structures, Phylogeny. Springer, Singapore

13 Singh K. Intellectual Property Protection in Bioinformatics and Open Bio Development [Internet]. Asian Biotechnology and Development Review; 2015 [cited 15 July 2020]. Available from: https://www.researchgate.net/publication/277016462_Intellectual_Property_Protection_in_Bioinformatics_a nd_Open_Bio_Development

${ }^{14}$ Nucleotide [Internet]. Genome.gov. 2020 [cited 13 July 2020]. Available from: https://www.genome.gov/genetics-glossary/Nucleotide ${ }^{15}$ Genes and human diseases [Internet]. World Health Organization. 2020 [cited 13 July 2020]. Available from: https://www.who.int/genomics/public/geneticdiseases/en/
} 


\section{Sanrachna}

bioinformatics because it enables modeling of protein structure and function prediction as well as it allows extracting knowledgeable information from the data in molecular biology ${ }^{16}$.

\section{Patent Eligibility of Bioinformatics in India}

In 1980, for the first time in a case Diamond v. Chakrabarty, the Supreme Court of USA allowed patentability of life forms by granting a patent for a recombinant bacterium ${ }^{17}$. Now the patentability of DNA is not permitted as in 2013 US Supreme Court in the case Association of Molecular Pathology v. Myriad Genetics ${ }^{18}$ overruled the decision in Diamond v. Chakrabarty and held that isolated DNA is not patentable because it is a product of nature while cDNA ${ }^{19}$ is patentable as it is an artificial material.

Certain guidelines issued by the Indian Patent Office (IPO) lays down the framework in respect of the examination of biotech applications for patents which expressed in the Indian Patent $\mathrm{Law}^{20}$.

Section 3- Following are not inventions/patentable within the meaning of the law: -

Section 3(B): The innovations which are contrary to morality or which cause serious prejudice to human, animal or plant life or health or environment ${ }^{21}$.

Section 3(C): A mere discovery of scientific principle or any type of formulation of an abstract theory or discovery of non-living or living substances occurring in nature ${ }^{22}$.

Section 3(D): Discovery of enhancement of a new form of the substance of the known efficacy or a mere discovery of a new property or process ${ }^{23}$.

\footnotetext{
${ }^{16}$ Karky R. Bioinformatics innovations and patent eligibility [Internet]. The Journal of World Intellectual Property, John Wiley \& Sons Ltd; 2018 [cited 10 July 2020]. Available from: https://onlinelibrary.wiley.com/doi/epdf/10.1111/jwip.12101

17 Shilpa, Gupta U. (2018) Intellectual Property Rights and Bioinformatics: An Introduction. In: Shanker A. (eds) Bioinformatics: Sequences, Structures, Phylogeny. Springer, Singapore

${ }^{18}$ Association for Molecular Pathology v. Myriad Genetics, Inc. [Internet]. Supremecourt.gov. 2013 [cited 14 July 2020]. Available from: https://www.supremecourt.gov/opinions/12pdf/12-398_1b7d.pdf

${ }^{19}$ cDNA is a complementary DNA which is DNA synthesised from a single stranded RNA.

${ }^{20}$ Biotechnology Patents- Subject Matter Exclusions [Internet]. Epgp.inflibnet.ac.in. 2020 [cited 15 July 2020]. Available from: http://epgp.inflibnet.ac.in/epgpdata/uploads/epgp_content/S000020LA/P000846/M010217/ET/15137596671 1_Q1e-text.pdf

${ }^{21}$ The Patents Act, 1970 [Internet]. Ipindia.nic.in. 2015 [cited 15 July 2020]. Available from: http://www.ipindia.nic.in/writereaddata/Portal/IPOAct/1_31_1_patent-act-1970-11march2015.pdf

22 Ibid

23 Ibid
} 


\section{Sanrachna}

Section 3(E): An admixture that results in aggregation of the property or a process of making such admixture.

Section 3(H): Process of Horticulture and Agriculture

$>$ Section 3(I): a process for medical treatments of human beings or any process for the treatment of animals.

Section 3(J): Animals and Plants in whole or any part thereof other than microorganisms but including seeds, varieties, and species and essentially biological processes for production ${ }^{24}$.

Section 3(K): Mathematical or business method or a computer program per se or algorithms ${ }^{25}$.

\section{Patent eligibility of bioinformatics software in India}

The criteria of getting a patent registration of software in India is to consider the substance of the claim considering the entire claim together and if there is a case where process or method, computer program or an algorithm, etc falls under the excluded range of patents then patent won't be granted until and unless where the claims are taken as a whole and don't fall under the excluded category. Moreover, one vital essential to get patent for software is that the algorithm, computer program shouldn't only pertain to software but also it should be linked to an invention which is applicable for industrial $u^{26} \mathrm{e}^{26}$.

\section{Evolution of Omics sciences}

Development in genetics has resulted in the advancement of the sciences of omics and system biology. Nowadays it has become possible to ascertain the whole DNA sequence of a genome as well as protein sequence in an organism because of the new emerging technologies and bioinformatics ${ }^{27}$. Omics is the part of biotechnology which analyses the functions and methods

\footnotetext{
${ }^{24}$ The Patents Act, 1970 [Internet]. Ipindia.nic.in. 2015 [cited 15 July 2020]. Available from: http://www.ipindia.nic.in/writereaddata/Portal/IPOAct/1_31_1_patent-act-1970-11march2015.pdf ${ }^{25}$ Biotechnology Patents- Subject Matter Exclusions [Internet]. Epgp.inflibnet.ac.in. 2020 [cited 15 July 2020]. Available from: http://epgp.inflibnet.ac.in/epgpdata/uploads/epgp_content/S000020LA/P000846/M010217/ET/15137596671 1_Q1e-text.pdf

${ }^{26}$ Mazumdar S. Bioinformatics Software: How Patentable it is in India when Software Patentability is not Allowed? [Internet]. Journal of Intellectual Property Rights Law; 2020 [cited 16 July 2020]. Available from: http://lawjournals.stmjournals.in ${ }^{27}$ The science of Omics: Historical perspective and possible significance to human health [Internet]. Longdom.org. 2020 [cited 16 July 2020]. Available from: https://www.longdom.org/conference-abstractsfiles/0974-276X.C1.081-002.pdf
} 


\section{Sanrachna}

of the given biological functions at different levels ${ }^{28}$. Understanding the DNA and Protein is vital which can determine genes responsible for diseases and interaction of drugs and proteins are generally significant because defective proteins can be the cause for several diseases ${ }^{29}$. Therefore, the advancement of the science of omics such as Genomics, Metabolomics, Epigenomics, proteomics, transcriptomics, phenomics has become crucial to understand human health and to be ready for any disease or any other health-related issues.

\section{Patent protection of Proteins, Genes and other Genetic materials in India}

\begin{tabular}{|l|c|}
\hline \multicolumn{1}{|c|}{ Particulars } & Patent Protection in India \\
\hline Genes or isolated DNA sequences & No \\
\hline cDNA sequences & Yes \\
\hline Altered, mutated or DNA sequences & Yes \\
\hline $\begin{array}{l}\text { Primers or probes derived from genes or isolated DNA } \\
\text { sequences or cDNA }\end{array}$ & Yes \\
\hline $\begin{array}{l}\text { Primers or probes derived from genes or isolated DNA } \\
\text { sequences or cDNA linked to a signal generating }\end{array}$ & Yes \\
\hline Kits to primers or probes & Yes \\
\hline Isolated protein sequences & No \\
\hline Fragments of isolated protein sequences & Yes \\
\hline Altered, mutated or variant protein sequences & \\
\hline
\end{tabular}

Patentability of Genes, Proteins and Other Genetic Materials ${ }^{30}$

\footnotetext{
${ }^{28}$ What is Omics | IGI Global [Internet]. Igi-global.com. 2020 [cited 20 July 2020]. Available from: https://www.igi-global.com/dictionary/risk-benefit-evaluation-in-clinical-research-practice/37529 ${ }^{29}$ The science of Omics: Historical perspective and possible significance to human health [Internet]. Longdom.org. 2020 [cited 16 July 2020]. Available from: https://www.longdom.org/conference-abstractsfiles/0974-276X.C1.081-002.pdf

${ }^{30}$ Patentability of Genes, Gene Sequencing \& DNA based Primers | [Internet]. Khuranaandkhurana.com. 2020 [cited 16 July 2020]. Available from: https://www.khuranaandkhurana.com/2015/10/09/patentability-ofgenes-gene-sequencing-dna-based-primers/
} 


\section{Sanrachna}

\section{Conclusion}

Around the globe, several revolutionary changes in the field of agriculture, botany, medicine, and others have brought by Bioinformatics. Currently while experiencing COVID-19 pandemic bioinformatics can play a vital role in the development of a vaccine or therapeutic drug via DNA sequencing. India is the first country worldwide to have a nationwide bioinformatics network (BTIS network) under the Department of Biotechnology (DBT). There are over 200 companies in India that are in some way or the other related to Bioinformatics ${ }^{31}$. A threshold of the eligibility of patent in the patent act gets faded by the patent manual guidelines such as in the guidelines DNA sequence claims are allowed but as per the 2013 IPO guidelines has curtailed the eligibility of DNA which is not isolated as it is a form of nature.

The absence of a definition for a microorganism and computer programs plus having a lack of judicial precedents have resulted in the lack of clarity on patenting of Bioinformatics. The intention of the legislature by biotechnology and patent guidelines are not clear as well. Also, it is determined that software programs cannot be patented in India but bioinformatics software is an invention where the inventor can obtain patent protection on the method if it yields tangible results. Therefore, it is observed that bioinformatics is a vital area in healthcare which indeed needs protection. Also, considering Digital India in the future, intellectual property should be given a higher pedestal when it comes to the protection of inventions especially in the field of bioinformatics.

In 2014, the US Supreme Court after 30 years in the case Alice Corp Pty Ltd. v. CLS Bank International $^{32}$ ruled $\mathrm{n}$ what types of computer-implemented patent claims can meet the patent eligibility, in other words, the needs to have an "inventive concept" that will help in making the claimed idea into a patent.

\footnotetext{
${ }^{31}$ Shenoy R. Bioinformatics Patents - The Challenges [Internet]. Journal of Commercial Biotechnology; 2016 [cited 15 July 2020]. Available from: https://www.researchgate.net/publication/312516488_Bioinformatics_Patents_-_The_Challenges

${ }^{32}$ Supremecourt.gov. 2014 [cited 20 July 2020]. Available from: https://www.supremecourt.gov/opinions/13pdf/13-298_7lh8.pdf
} 